\title{
Phenotypic and Genotypic Characterizations of Aeromonas hydrophila Complex Isolated from Fresh and Frozen Beef and Poultry Meats
}

\author{
Enany, M. E. ${ }^{1}$, Youssef, A. I ${ }^{2}$., Hanora, A. M. ${ }^{3}$, and Afify, A. F. ${ }^{4}$ \\ ${ }^{1}$ Department of Bacteriology, Immunology and Mycology, ${ }^{2}$ Department of \\ Animal Hygiene and Zoonoses, Faculty of Veterinary Medicine, \\ ${ }^{3}$ Department of Microbiology, Faculty of Pharmacy and ${ }^{4}$ Meat inspector \\ veterinarian, Veterinary medicine, Suez Canal University, Ismailia, Egypt \\ Ismailia, Egypt.
}

*Corresponding author :Email: address: ahmed_ibrahim@vet.suez.edu.eg

\begin{abstract}
This study was aimed to identify the phenotypic and geneotypic characteristics of Aeromonas hydrophila isolated from fresh and frozen beef and poultry meat, determine its harmfulness, and identify the sources of contamination of meat. To achieve these objectives, a total of 200 bacteriological swabs was collected from meat as following: (66) fresh beef, (43) fresh poultry meat, (57) frozen beef and (34) frozen poultry meat. In addition, 9 swabs from the hands of the workers who handling meat and also 5 samples of washing water used in the slaughterhouse and meat retail shops. The samples were examined by microbiological and biochemical screening tests followed by molecular biological and examined some of aerolysin, lipase and enterotoxin genes by PCR. The results revealed that out of 200 meat swabs samples, $129(64.5 \%)$ were positive for Aeromonas spp. Out of 9 samples from workers' hands, $6(66.67 \%)$ was identified to Aeromonas spp.. However, the 5 water samples was negative for Aeromoans spp.. Biochemical characterization identified to species level of 129 Aeromonas strain isolates identified to the $A$. hydrophila $(\mathrm{no}=112 ; 86.82 \%)$, and other motile Aeromonas spp. (no= $17 ; 13.18 \%)$. Concerning the bacteriological examination of samples from worker hands, $5(83.34 \%)$ out of 6 samples was identified as $A$. hydrophila and $1(16.66 \%)$ was identified to other motile Aeromonas spp. The prevalence of $A$. hydrophila of Fresh meet $(74.31 \%)$ was significantly higher than that in frozen meat $(47.25 \%)$ at $<0.01$. Results revealed that out of 45 isolates from samples, the rate of aero A, lip and act genes were $31.11 \%, 22.22 \%$, and $73.33 \%$, respectively. Results of this study revealed that there is a clear presence of $A$. hydrophila strains isolated from frozen and
\end{abstract}


fresh meat and worker hands, as well as high levels of genes responsible for the virulent microbe indicate the presence of a potential risk of infection from food poisoning.

Keywords: Aeromonas hydrophila; Meat; Aerolysin; Lipase; Enterotoxins; Zoonosis

\section{Introduction}

Aeromonads are autochthonous to aquatic environments worldwide. They have been isolated from a variety of raw foods. Members of this genus tolerate temperatures ranging from 4 to $42^{\circ} \mathrm{C}$ and are known to cause a diverse spectrum of diseases in both warm- and coldblooded animals (Fricker and Tompsett, 1989; Martinez-Murcia et al, 1992). Only five species of Aeromonas were recognized, three of which (A. hydrophila, A. Veronii biovar sobria, and $A$. caviae) existed as phenospecies, that is, a named species containing multiple DNA groups. The members of which could not be distinguished from one another by simple biochemical characteristics. Each of these three species contained at least two or three distinct genotypes or hybridization groups (Popoff et al, 1981; Janda and Abbott, 1998). The comparative analysis of the $16 \mathrm{~S}$ rRNA gene sequence for Aeromonas species generally correlates well with DNA-DNA hybridization studies and phylogenetic analyses based on this gene indicated that Aeromonads are phylogenetically a very tight group of species (Fontes et al, 2011). A. hydrophila is a Gram negative rod, motile by means of polar flagella. It could usually be isolated and typed within 24 hours by cytochrome oxidase positive, fermentative and oxidative (Roberts, 1978).

Aeromonas spp. are recognized as potential food-poisoning agents. $A$. hydrophila is psychrotrophic and has been associated with the spoilage of refrigerated animal products including chicken, beef, pork, lamb, fish, oysters, crab, and milk (Buchanan and Palumbo, 1985; El-Shenawy and Marth, 1990). Both raw and cooked foods are potential sources for infecting human beings with Aeromonas spp. (Ventura et al, 1998). These bacteria have been recognized as enteric pathogen for human, and animal (Zaki et al, 2001 and Vila et al, 2003). The Bacteria have been implicated in diverse pathogenic conditions varying from gastroenteritis, meningitis and septicaemia (Paniagua et al, 1990; Borrego et al, 1991; Efuntoya, 1995). The genus Aeromonas comprises important human pathogens causing primary and secondary septicaemia in immunocompromised persons, 
serious wound infections in healthy individuals and in patients undergoing medical leech therapy (Fontes et al, 2011). Actual Aeromonas foodborne outbreaks are few, but the epidemiological evidence suggests that the bacterium can cause self-limiting diarrhoea, with children being the most susceptible population (Isonhood and Drake, 2002).

The epidemiological studies indicated that Aeromonas foodborne disease associated to meat and meat products are the animal intestinal tract and the processing environment by contamination. The human being is also an important source of pathogens, most frequently by cross contamination, as well as by the supplying water (Hardly et al, 1986; Fontes et al, 2011).

Polymerase chain reaction (PCR) is a rapid highly sensitive, with a capacity to amplify from even a single molecule of DNA (Elshafey, 2000). PCR is a sensitive and specific tool for detection of Aeromanas species and its virulence genes. The detection of virulence factors of $A$. hydrophila such as cytolytic enterotoxin (Act), hemolysin(hyl H)/aerolysin (Aero A), lipases (Lip) and proteases is a key component in determining potential pathogenicity because these factors act multifunctionally and multifactorially (Yogananth et al, 2009).
The main objectives of this study were to determine the rate of contamination of Aeromonas spp of fresh and frozen meat obtained from slaughterhouses and markets as well as meat handlers with focusing on A. hydrophila; determine the phenotypic and genotypic characteristics of isolated Aeromonas spp. strains; and to estimate of the public health impacts of $A$. hydrophila contamination of meat.

\section{Material and methods}

\section{Sample collection}

A total number of 200 swabs samples were collected from 66 fresh beef, 43 fresh poultry meat, 57 frozen beef, and 34 frozen poultry meat. In addition, 9 swabs from hands of the workers who were handling meat as well as 5 water samples used for washing in the slaughterhouse and meat retail markets.

The swab contact method was applied sampling according to (Harrigan, 1998). In this method, a sterile cotton swab was dipped in a sterile normal saline and the swab was rubbed over a selected area, rolling back and forth and crosscross to thoroughly cover the few square inches involved. The swab was dipped back into the sterile solution several times during the cleaning. The final step was to break off the tip of the swab and was placed it in the solution. The tube was shaken hard and the 
solution was subsequently used for microbiological tests.

Swabs were inoculated into separated tube contained normal saline immediately after collection and quickly transported in ice to the laboratory zoonozes, Faculty of Veterinary Medicine, Suez Canal University.

\section{A. Fresh samples}

Swab samples were collected from cattle carcasses after being slaughtered at Ismailia slaughterhouse which is located at Ismailia city, Egypt before chilling of the carcasses or meat processing. Swabs were collected from the neck and the flank regions of each cattle beef carcass. These regions are the most likely to exposure to contamination, either the animal itself or the surrounding environment.

Swab samples from fresh chicken meat were collected from public markets in Ismailia city, Egypt. These shops were selling live birds, chicken meat and chicken meat products. All the chicken were manually slaughtered at the shop, de-feathered, eviscerated and deboned at the shop under unhygienic conditions.

\section{B. Frozen samples}

Frozen samples were collected randomly from selected local retail shops and supermarkets located at Ismailia city, Egypt. Frozen beef was imported meat while frozen chicken meat was slaughtered and packed at semi-automatic and automatic slaughterhouses under good hygienic conditions in Egypt.

\section{Worker hands samples}

A total of 9 swabs were collected from hands of workers who handling meat from the 4 swabs from hands of the slaughterhouse workers and 5 swabs from hands of workers who handling meat at the retail shops.

\section{Water samples}

The water samples were collected and treated according procedures described in standard methods for the examination of water and wastewater according to Andrew et al (2005).

Five water samples $(200 \mathrm{ml})$ were collected from tape water used for washing as following: one sample of abattoir, another one of poultry slaughtering places and 3 samples of local retail shops. The samples were taken in sterile glass bottles capacity $200 \mathrm{ml}$, the bottles were fitted with glass stoppers and were previous sterilized by autoclaving. Water samples were shacked well after added thiosulphate $(4 \mathrm{ml})$ to dechlorinate the water samples then $(1 \mathrm{ml})$ of the dechlorinated water sample was added to $10 \mathrm{ml}$ in trypticase soya broth supplemented with $10 \%$ ampicillin as enrichment media and incubated at $37{ }^{\circ} \mathrm{C}$ for 24-48 hrs.

2. Isolation and identification of Aeromonas species

\section{A. Phenotypic identification.}

Isolation and identification of Aeromonas spp. from the collected 
samples were adopted from the schemes demonstrated by Berge's Manual of Systemic Bacteriology; Krieg and Holt (1984). Confirmation of the isolates was occurred by PCR amplification.

\section{B. Pre-enrichment of the samples}

Upon received to the laboratory, the swabs suspended in $5 \mathrm{ml}$ of sterile saline solutions were mixed well. Afterword, $1 \mathrm{ml}$ of each tube was added under aseptic conditions to another tube containing $10 \mathrm{ml}$ tryptone soy broth (Difco) supplemented with $10 \%$ ampicillin and incubated at $37^{\circ} \mathrm{C}$ for $24-48 \mathrm{hrs}$.

C. Culturing of samples on selective media

A loopful from each tube were taken and streaked over the following media trypticase soya agars (Difco), RS agar (Difco), MacConkey agar (Oxoid) and Aeromonas base medium (Difco) by using sterile platinum loop and incubated at $37{ }^{\circ} \mathrm{C}$ for $24-48 \mathrm{hrs}$.

\section{Sub-culturing and preservation} of the suspected colonies

Typical isolated colonies were subcultured again on nutrient agar plates to confirm their purity then transferred on nutrient agar slant for further biochemical test and in semisolid agar for motility test and preservation. The strains were maintained at $-4{ }^{\circ} \mathrm{C}$ in semisolid nutrient agar containing $20 \%$ Glycerol.

\section{E. Biochemical examination}

The suspect purified colonies were screened using determinant biochemical according to MacFaddin (2000) and Oxoid (1995). Biochemical tests were performed using the following test: oxidase test, catalase test, indole production, triple sugar iron agar Vibriostatic agent $0 / 129$, citrate utilization test, esculin hydrolysis, Voges-proskauer reaction, Sugar fermentation test, hemolysis on sheep blood agar and growth on MacConkey agar and in nutrient broth with and without $6 \% \mathrm{NaCl}$.

Semi- solid media $0.5 \%$ Nutrient agar medium (Oxoid) supplemented with $\mathrm{NaCl} 2 \%$ was used for preservation and detection of motility of the isolated strains.

F. Detection of $16 S$ rRNA gene and virulence genes by PCR

All biochemically positive isolates were confirmed to be Aeromonas spp. by $16 \mathrm{~S}$ rRNA gene amplification using primers and amplification conditions as described by Arora et al (2006). In addition, PCR amplification of the virulence genes Aero A, Act and lip genes from chromosomal DNA was performed. Different sets of the primers and amplification conditions were tabulated in Table 1.

3. Bacterial DNA extraction for PCR.

All strains were re-identified on the basis of 16S r RNA. Extraction of DNA from bacterial isolates was performed by boiling of the isolates according to Van Eys et al (1989). One $\mathrm{ml}$ of fresh bacterial broth 
culture was centrifuged at $5000 \mathrm{rpm}$ for $5 \mathrm{~min}$, then the supernatant was discarded and the pellet was resuspended in $1 \mathrm{ml}$ of distilled water then centrifuged at $5000 \mathrm{rpm}$ for $5 \mathrm{~min}$ followed by discarding the supernatant. This washing process of the pellet was repeated more two times. Afterwards, the pellet was re-suspended in $200 \mu$ l of distilled water. The suspension was boiled for $10 \mathrm{~min}$, placed on ice for $5 \mathrm{~min}$, and then centrifuged for 5 min in a microcentrifuge at 10,000 rpm. Finally, the supernatant solution was separated in $0.5 \mathrm{ml}$ sterile tubes and kept at $-20{ }^{\circ} \mathrm{C}$ until used in PCR reactions. Subsequently, $5 \mu \mathrm{l}$ of the DNA solution was used as a=template for PCR amplification. Aeromonas strains ATCC 7966, ATCC 43979 were included as quality controls.

\section{A. PCR amplification reactions}

Each PCR reaction mixture consisted of a final volume of $25 \mu 1$ divided to $5 \mu \mathrm{l}$ of the extracted DNA, $12.5 \mu 1$ of $2 X$ PCR Master Mix (Bioteke gorporation) $[20 \mu 1$ of Phosphate buffered saline (PBS) $\mathrm{pH}$ 7.3., Ten volumes of Tris-EDTA buffer (TE) pH 8.0, $1.5 \mathrm{mM} \mathrm{MgCl2}$, $10 \mathrm{mM}$ Deoxy Nucleotide Triphosphate solution (dNTPs) and Ampli Taq DNA polymerase (1unit/ $\mu 1)$ ], $0.5 \mu 1$ of each primer ( 5 pmol concentration) and $6.5 \mu 1$ sterile distilled water. The PCR assays were performed using a Thermal Cycler (Eppendorf). The primers were ordered from Operon
Company, (Operon, Japan) as nucleotide sequence. All primers were diluted according to the company instructions using sterile distilled water.

The amplification procedure consisted of an initial denaturation step at $94{ }^{\circ} \mathrm{C}$ for $2 \mathrm{~min}$, followed by 30 cycles with denaturation at $94{ }^{\circ} \mathrm{C}$ for $1 \mathrm{~min}$, annealing for $1 \mathrm{~min}$ at 56 ${ }^{\circ} \mathrm{C}$ for 16 rRNA gene, $52 \mathrm{C}$ for the aerA gene or $60{ }^{\circ} \mathrm{C}$ for the act gene or $55{ }^{\circ} \mathrm{C}$ for the Lip gene and extension at $72{ }^{\circ} \mathrm{C}$ for $1 \mathrm{~min}$. A final extension step was carried out at 72 ${ }^{\circ} \mathrm{C}$ for $5 \mathrm{~min}$. Aliquots from amplification reactions were analyzed by $1 \%$ agarose gel electrophoresis and viewed and photographed under UV light using gel documentation system (Biospectrum 310 imaging system).

\section{Statistical analysis}

Chi-square was used for calculation of significance between the prevalence rate of $A$. hydrophila of fresh and frozen meat at $<0.01$.

\section{Results}

\section{Phenotypic characterization of} A. hydrophila spp.

Identification of $A$. hydrophila complex depended mainly on the colonial appearance, microscopic examination of the stained smears, and biochemical examination.

Phenotypic characterization of $A$. hydrophila strains revealed that the shape of the suspected colonies onto the surface of different media was as following: trypticase soya agar 
medium: the colonies appeared as creamy color, glist convex. MacConkey agar medium: the colonies appeared as large, flat and non-lactose fermenting. R-S agar medium:only the yellow colonies were considered A. hydrophila. Aeromonas base medium supplemented with ampicillen: the colonies appeared yellow. Stained smears from colonies with Gram's stain and examined microscopically under oil immersion lens appeared as Gram negative, non-sporulated and short rod-shaped. Suspected purified isolates were identified by using the following test: oxidase test, catalase test, indole production, Vibriostatic agent 0/129, citrate utilization test, esculin hydrolysis, Voges-Proskauer reaction, Sugar fermentation test. With regarded to the biochemical characters of isolates, $A$. hydrophila characterized by motile and positive in oxidase, catalase, indole proudaction, esculin hydrolysis, Voges-proskauer, Vibriostatic agent 0/129 resistant, TSI biochemical reaction whereas negative for Citrate utilization. The isolates were observed for a clear zone of $\beta$-hemolysis around the colonies.

2. Total prevalence of $A$. hydrophila among the examined samples

As shown in Table 2, the results revealed that out of 200 meat swabs samples, 129 (64.5\%) were positive for Aeromonas spp. and 71 (35.5\%) were negative. Out of 9 samples from workers' hands, 6 (66.67\%) were identified as Aeromonas spp. And 3 (33.33\%) were negative. However, the 5 water samples were negative for Aeromoans spp..

Biochemical characterization identified to species level the 129 Aeromonas strain isolates into the A. hydrophila (no $=112 ; 86.82 \%)$, other motile Aeromonas spp. (no= $17 ; 13.18 \%$ ). Concerning the bacteriological examination of samples from worker hands, 5 $(83.34 \%)$ out of 6 samples were identified as A. hydrophila and 1 $(16.66 \%)$ was identified to other motile Aeromonas spp.

\section{Comparison of the contamination rate of $A$. hydrophila among Fresh and Frozen meat.}

As shown fig. 1, the rate of contamination in fresh beef and chicken meat with $A$. hydrophila was 81/109 (74.31\%) which was much higher compared with frozen chicken and beef meat 43/91 (47.25\%). The prevalence of $A$. hydrophila of Fresh meet was significantly higher than that in frozen meat at $<0.01$.

As shown fig. 1, A hydrophila was detected in 49 out of $66(74.24 \%)$ of isolates from fresh beef samples and 32 out of $43(74.42 \%)$ samples of fresh poultry meat. On the other hand, the positive results of frozen beef and frozen poultry meat isolates reached 24 out of 57 $(42.11 \%)$ and 19 out of 34 (55.88\%), respectively. 
4. Comparison of bacteriological culturing and PCR amplification for identification of $\boldsymbol{A}$. hydrophila. As shown in Table 3, 117 (54.67\%) out of 214 total samples were positive for $A$. hydrophila by using the standard bacteriological techniques. However, PCR amplification of $16 \mathrm{~S}$ rRNA gene revealed $129(60.28 \%)$ of the isolates were confirmed to Aeromonas spp.

5. Virulence genes detection by PCR amplification of 10 isolates from each sample types

As shown in table 4, the obtained results of PCR of different genes:

For detection of some virulence factors, a total of 40 isolates of $A$. hydrophila from meat (10 from each category) and 5 isolates from meat handlers were examined by gene specific primers.

Results revealed that out of 45 isolates from samples, $14(31.11 \%)$ were aero $A$ gene positive by PCR amplification yielded band at 252 $\mathrm{pb}$. The detection rate of aero $A$ gene was $30 \%, 10 \%, 50 \%$, and $20 \%$ among fresh beef, frozen beef, fresh poultry and frozen poultry, respectively. Among 5 isolates from meat handlers' hands, 3 (60\%) was positive for aero $A$ gene.

Results showed that out of 45 isolates from samples, $10(22.22 \%)$ was lip gene positive by PCR amplification yielded a band at 760 bp. The detection rate of lip gene was $30 \%, 0 \%, 40 \%$, and $20 \%$ among fresh beef, frozen beef, fresh poultry and frozen poultry, respectively. Among 5 isolates from meat handlers' hands, $1(20 \%)$ was positive for lip gene.

By act gene specific primers, the PCR results revealed that out of 45 isolates from samples, $33(73.33 \%)$ was act gene positive by PCR amplification yielded band at 232 bp. The detection rate of act gene was $80 \%, 40 \%, 90 \%$, and $70 \%$ among fresh beef, frozen beef, fresh poultry and frozen poultry, respectively. Among 5 isolates from meat handlers' hands, $4(80 \%)$ was positive for act gene.

Table 1: PCR primers sequence used for detection of different target genes.

\begin{tabular}{|c|l|l|l|l|l|}
\hline No & Target gene & Forward Primer & Reverse Primer & $\begin{array}{l}\text { Amplicon } \\
\text { size }\end{array}$ & Reference \\
\hline 1 & 16S rRNA & $\begin{array}{l}\text { 5-TCA TGG CTC AGA } \\
\text { TTG AAC GCT-3 }\end{array}$ & $\begin{array}{l}\text { 5-CGG GGC TTT CAC } \\
\text { ATC TAA CTT ATC-3 }\end{array}$ & $599 \mathrm{bp}$ & Graf(1999) \\
\hline 2 & aerolysin & $\begin{array}{l}\text { 5-GCA GAA CCC ATC } \\
\text { TAT CCA G-3 }\end{array}$ & $\begin{array}{l}\text { 5-TTT CTC CGG TAA } \\
\text { CAG GATTG-3 }\end{array}$ & $252 \mathrm{bp}$ & $\begin{array}{l}\text { Santos, et al. } \\
(1999)\end{array}$ \\
\hline 3 & $\begin{array}{l}\text { cytotoxic } \\
\text { enterotoxin }\end{array}$ & $\begin{array}{l}\text { 5-AGA AGG TGA CCA } \\
\text { CCA AGA ACA-3 }\end{array}$ & $\begin{array}{l}\text { 5-AAC TGA CAT CGG } \\
\text { CCT TGA ACT C-3 }\end{array}$ & 232 bp & $\begin{array}{l}\text { Kingombe, et } \\
\text { al. (1999) }\end{array}$ \\
\hline 4 & $\begin{array}{l}\text { Lipase } \\
\text { gene }\end{array}$ & $\begin{array}{l}\text { 5-AACCTGGTTCCGC } \\
\text { TCAAGCCGTTG-3 }\end{array}$ & $\begin{array}{l}\text { 5- TTGCTCGCCTCG } \\
\text { GCCCAGCAGCT-3 }\end{array}$ & 760 bp & $\begin{array}{l}\text { Cascón, et al. } \\
\text { (1996) }\end{array}$ \\
\hline
\end{tabular}


Table 2: The total prevalence of A. hydrophila spp among examined samples.

\begin{tabular}{|c|c|c|c|c|c|c|c|c|}
\hline \multirow{3}{*}{$\begin{array}{l}\text { Total number of } \\
\text { examined samples }\end{array}$} & \multicolumn{4}{|c|}{$\begin{array}{l}\text { Total prevalence of Aeromoans } \\
\text { spp. }\end{array}$} & \multicolumn{4}{|c|}{ Total A.hydrophila sp. prevalence } \\
\hline & \multicolumn{2}{|c|}{ Total positive } & \multicolumn{2}{|c|}{$\begin{array}{l}\text { Total } \\
\text { negative }\end{array}$} & \multicolumn{2}{|c|}{ A. hydrophila } & \multicolumn{2}{|c|}{$\begin{array}{l}\text { Other motile } \\
\text { Aeromonas spp. }\end{array}$} \\
\hline & No & $\%$ & No & $\%$ & NO & $\%$ & NO. & $\%$ \\
\hline Meat $(\mathrm{No}=200)$ & 129 & $64.5 \%$ & 71 & $35.5 \%$ & $112 / 129$ & 86.8 .2 & $17 / 129$ & $13.18 \%$ \\
\hline Human $(\mathrm{No}=9)$ & 6 & $66.67 \%$ & 3 & $33.33 \%$ & 5 & $83.34 \%$ & 1 & 16.66 \\
\hline $\begin{array}{l}\text { Water samples } \\
(\mathrm{No}=5)\end{array}$ & 0 & 0 & 5 & $100 \%$ & 0 & 0 & 0 & 0 \\
\hline
\end{tabular}

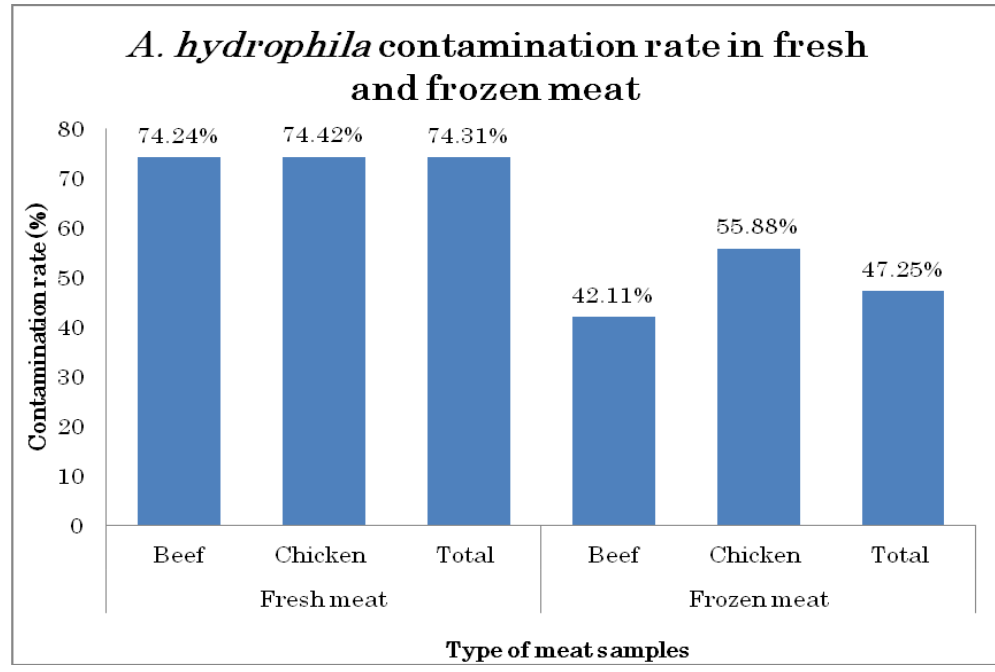

Fig 1: Comparison of the contamination rate of A. hydrophila among fresh and frozen meat.

Table 3: Comparison of bacteriological culturing and PCR amplification for identification of A. hydrophila

\begin{tabular}{|c|c|c|c|c|}
\hline \multirow{2}{*}{ Source of samples } & \multicolumn{2}{|c|}{$\begin{array}{c}\text { Bacteriological } \\
\text { culture }\end{array}$} & $\begin{array}{c}\text { PCR amplification } \\
\text { 16SrRNA }\end{array}$ \\
\cline { 2 - 5 } & No. & \% & No. & \% \\
\hline Total meat samples No=200 & 112 & $56 \%$ & 124 & $61.5 \%$ \\
\hline Workers hand's No $=9$ & 5 & $66.67 \%$ & 5 & $66.67 \%$ \\
\hline Water samples No $=5$ & 0 & $0 \%$ & 0 & $0 \%$ \\
\hline Total No $=214$ & 117 & $54.67 \%$ & 129 & $60.28 \%$ \\
\hline
\end{tabular}




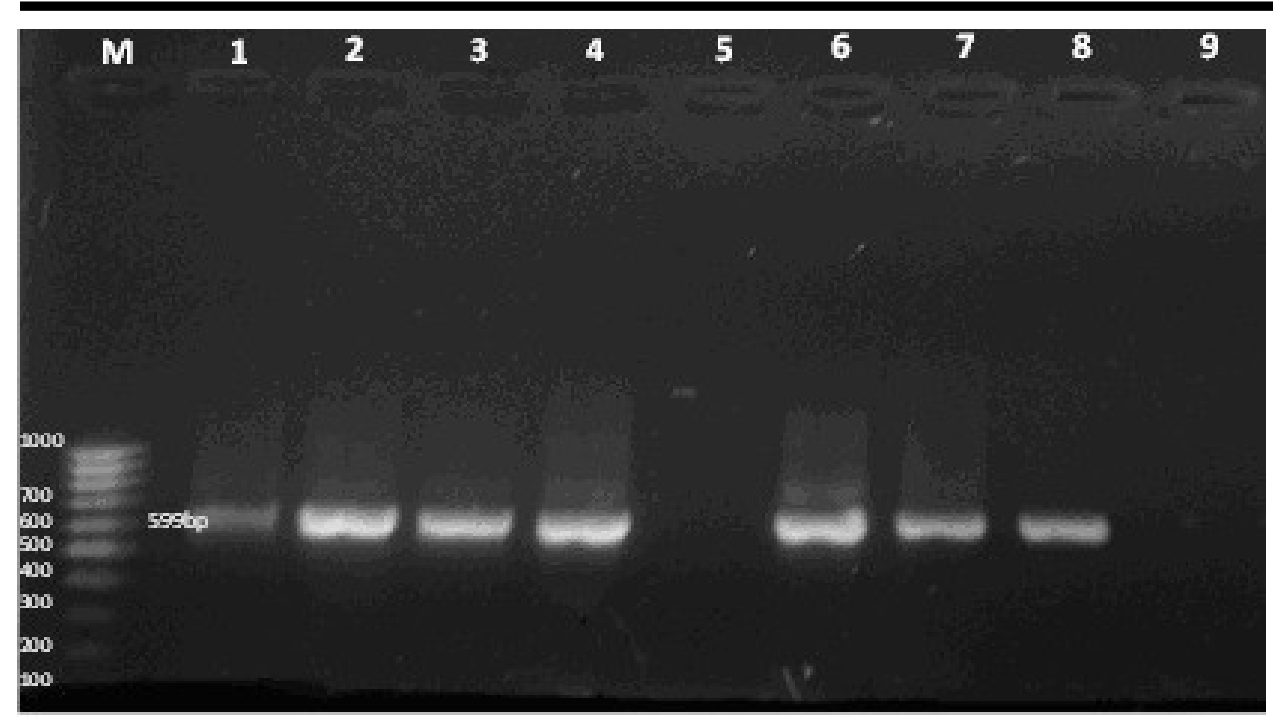

Fig 2: PCR amplification of 16rRNA of Aeromonas spp Lane M: showing DNA marker ladder (100-1000 bp).

Lane 1 and 7: showing DNA A. hydrophila isolated from fresh beef.

Lane 2: showing DNA A. hydrophila isolated from frozen beef.

Lane 3: showing DNA A. hydrophila isolated from fresh poultry meat.

Lane 4: showing DNA A. hydrophila isolated from frozen poultry meat.

Lane 5: showing negative sample.

Lane 6: showing DNA A. hydrophila isolated from human hand.

Lane 8: showing DNA of reference A. hydrophila strain (positive control).

Lane 9: showing control negative.

Table 4: Prevalence of some virulence gene in 10 samples of each meat samples and meat handler samples

\begin{tabular}{|c|c|c|c|c|c|c|}
\hline \multirow{2}{*}{ Source of samples } & \multicolumn{2}{|c|}{ Aerolysin gene } & \multicolumn{2}{|c|}{ Lipase gene } & \multicolumn{2}{|c|}{ Enterotoxin gene } \\
\hline & No. & $\%$ & No. & $\%$ & No. & $\%$ \\
\hline Fresh beef No $=10$ & 3 & $30 \%$ & 3 & $30 \%$ & 8 & $80 \%$ \\
\hline Frozen beef No $=10$ & 1 & $10 \%$ & 0 & $0 \%$ & 4 & $40 \%$ \\
\hline Fresh poultry meat $\mathrm{No}=10$ & 5 & $50 \%$ & 4 & $40 \%$ & 9 & $90 \%$ \\
\hline Frozen poultry Meat $\mathrm{No}=\mathbf{1 0}$ & 2 & $20 \%$ & 2 & $20 \%$ & 7 & $70 \%$ \\
\hline Total meat $\mathrm{No}=40$ & 11 & $27.5 \%$ & 9 & $22.5 \%$ & 28 & $70 \%$ \\
\hline Worker's hands No $=5$ & 3 & $60 \%$ & 1 & $20 \%$ & 4 & $80 \%$ \\
\hline Total No $=45$ & 14 & $31.11 \%$ & 10 & $22.22 \%$ & 33 & $73.33 \%$ \\
\hline
\end{tabular}




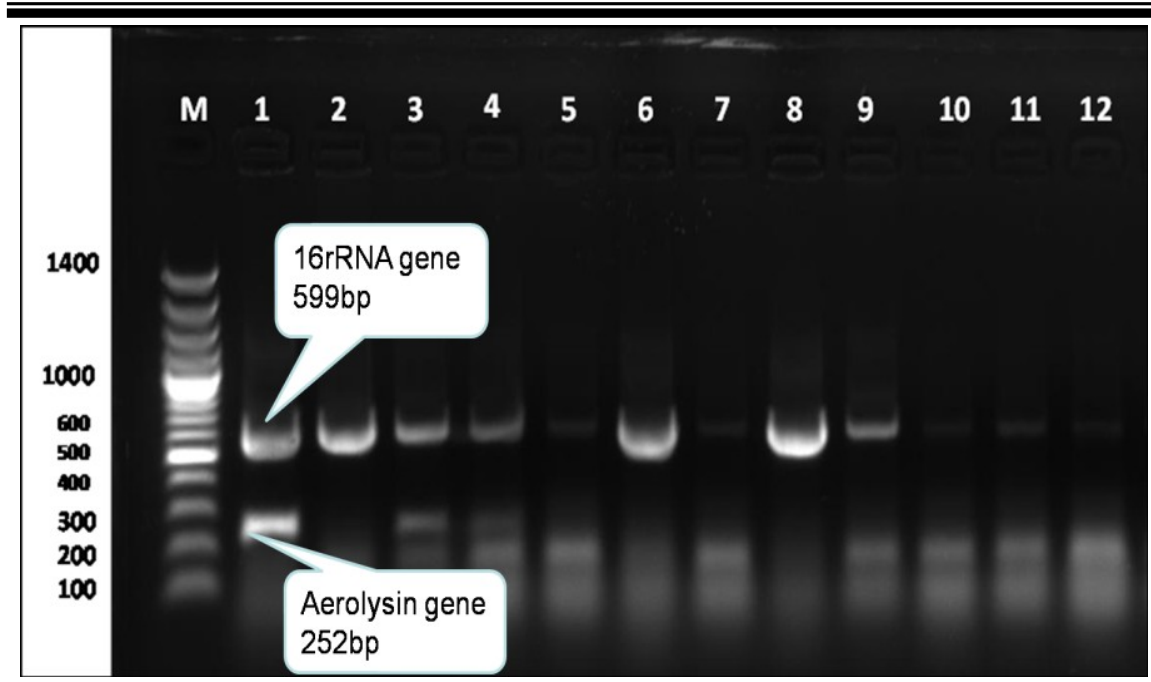

Fig 3: Amplification of the aerolysin gene from isolates of A. hydrophila of frozen beef samples

As shown in fig. (3) A Duplex PCR reaction of 16rRNA gene and Aerolysin gene. Amplification of the aerolysin gene from ten isolates of $A$. hydrophila of frozen poultry samples at $252 \mathrm{bp}$.

Lane M: showing DNA marker ladder (100-1400 bp).

Lane 1: showing control positive.

Lane 2: showing control negative.

Lane 3: showing amplification product at 252 bp fragment characterisitic for aerolysin gene from isolates.

Lane 4, 5, 6, 7, 8, 9, 10,11 and 12 showing negative.

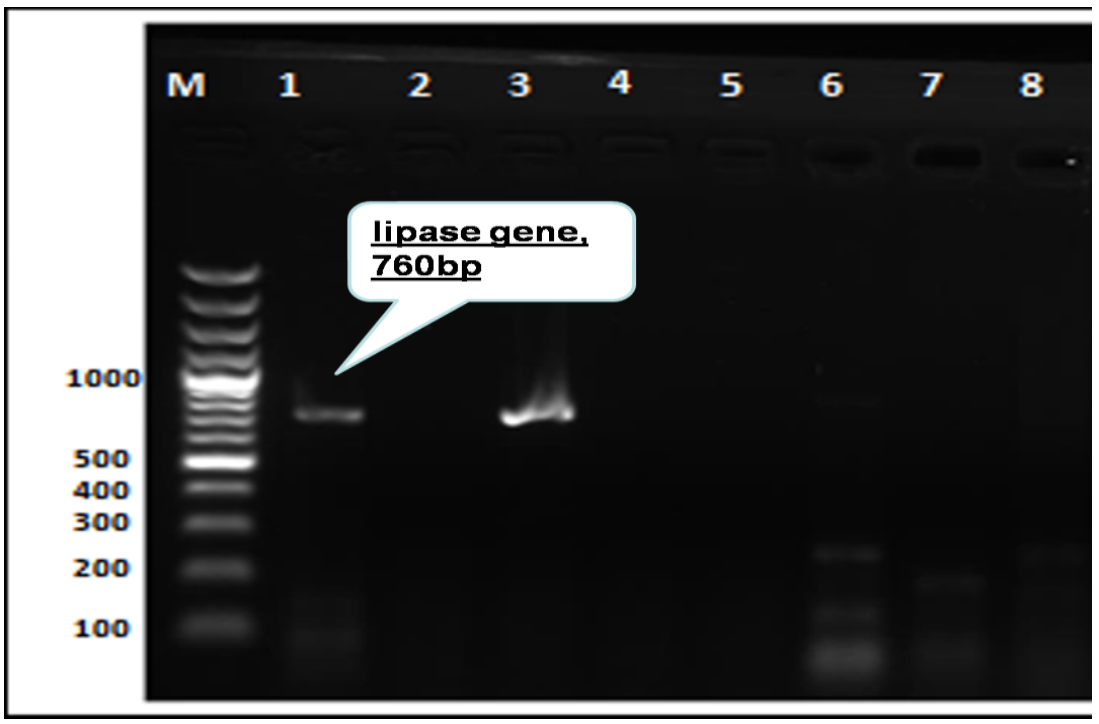


Fig 4: Amplification of the lipase gene from isolates of A. hydrophila of Worker's hands samples

As shown in fig. (4) Amplification of the lipase gene from ten isolates of A. hydrophila of fresh poultry meat samples at $760 \mathrm{bp}$.

Lane M: showing DNA marker ladder (100-1400 bp).

Lane 1: showing control positive.

Lane 2: showing control negative.

Lane 3: showing amplification product at $760 \mathrm{bp}$ fragment characteristic for lipase gene from isolates.

Lane 4, 5, 6, 7 and 8 : showing negative.

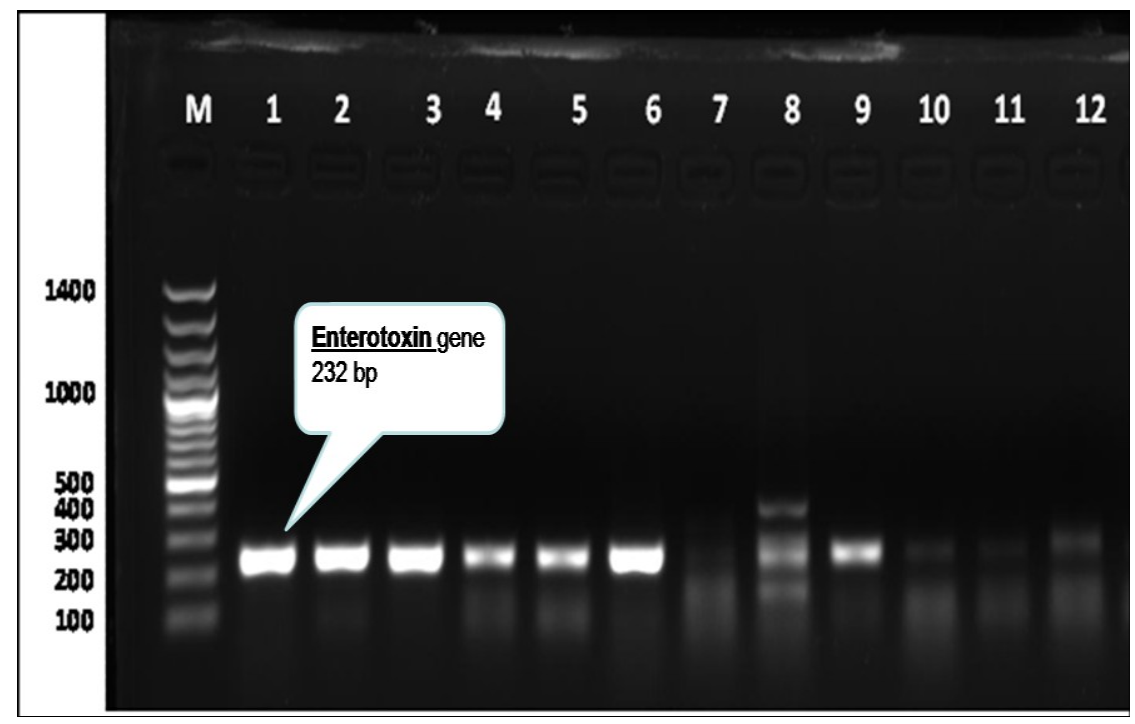

Fig 5: Amplification of the enterotoxin gene from isolates of A. hydrophila of fresh poultry meat samples

As shown in fig. (5) Amplification of the enterotoxin gene from ten isolates of A. hydrophila of fresh poultry meat samples at $232 \mathrm{bp} D N A$ ladder.

Lane M: showing DNA marker ladder (100-1400 bp).

Lane 1: showing control positive.

Lane 2, 3, 4, 5, 6, 8, 9, 10, 11 and 12 showing amplification product at 232 bp fragment characteristic for lipase gene from isolates.

Lane 7: showing negative.

\section{Discussion}

Aeromonas species have been significance of Aeromonas in foods recognized as potential or emerging foodborne pathogens. Although the remains undefined, the isolation of Aeromonas strains from a variety of 
retail foods may indicate that these products can act as possible vehicles for the dissemination of food-borne Aeromonas gastroenteritis (Neyts et al, 2011). The findings of this study indicated high predominance of $A$. hydrophila strains among food and meat handlers. This result was in consistent with that detected by (Fricker and Tompsett, 1989) who mentioned that all members of the A. hydrophila complex were predominant in the fish, meat and poultry samples. In this study, fresh samples were collected from the slaughterhouse and public live bird markets while frozen samples were collected from retail markets. Therefore, many factors could affect the rate of contamination of meat products including hygienic measures, proper handling and methods of meat preparations. The high prevalence of meat contamination by $A$. hydrophila might be due to collection of the swabs from the neck and the flank region of each cattle carcass and the neck and the around visceral cavity of each eviscerated poultry carcass. These regions are the most likely to exposure to contamination, either the animal itself or the surrounding environment such as workers.

The obtained results demonstrated the presence of various Aeromonas spp. with virulence potential in different meat products marketed. Phenotypic characterisation of $A$. hydrophila strains was agreed with finding of previous researches (Amin, 1993; Abd El-Rahman, 1996; Shalaby, 1997 and Megahed, 2000). Generally, $A$. hydrophila strains were isolated from fresh meat samples with percentage of $74.24 \%$. These results nearly were similar to the findings of Neyts et al (2000) in Belgium and higher than that recorded by Osman et al (2012) in Egypt. However, it was nearly similar to that Hanninen et al (1995) in Finland. On another hand, $A$. hydrophila was isolated from fresh poultry meat samples with percentage $74.42 \%$. This result nearly agreed with that of Hanninen et al (1995) in Finland however it was much higher than that detected by Kumar et al (2000). A. hydrophila was isolated from frozen meat samples with percentage of $47.25 \%$. This result more than Osman et al (2012). The highest percentage of $A$. hydrophila isolates from samples of fresh beef meat might be due to the source of the samples. These samples were collected from manual slaughterhouse subsequently it was more likely to be contaminated both during the process of skinning out of the hands of workers and the evisceration of visceral content. On the other hand, the frozen cattle beef the percentage of $A$. hydrophila isolates gave the lowest rate. These results could be attributed to the origin of this meat where it was imported or the effect 
of long freezing or handling during selling in the markets.

The importance of the genus Aeromonas in human disease has recent become better appreciation through the use of improved methodology for the recovery and identification of Aeromonas from biological specimen. In the present study, results showed that molecular examination was much sensitive technique compared to standard microbiological techniques. This demonstrated that PCR examination was a sensitive, rapid and reliable technique for examination of $A$. hydrophila. The PCR was a molecular technique which could be used to identify specific bacterial strains within a mixed population. Moreover, it provides results at a fraction of the time required by the cultured techniques $24 \mathrm{hrs}$ compared with 2-6 days (Delabre et al, 1998; Hiney and Smith, 1998). PCR protocols do not require any sophisticated equipment and time of processing is very less as compared to other methods. Thus, it is apt for large scale testing of samples (Surendran 2002).

The human being is also an important source of pathogens, most frequently by cross contamination (Borch and Arinder, 2002). In this study, detection of infection in slaughterhouse workers indicated that they could be a potential source of infection with Aeromonas and could act as silent carriers of infections. Thus, regular health check of food handlers and examination of drinking water are very important measure for decreasing food borne infection of Aeromonas. Aeromonads are not resistant to food processing regimes and readily killed by heat treatment (Isonhood and Drake, 2002). Therefore, efficient cooking of the food is important.

Drinking water and foods are reservoirs of Aeromonas and therefore may be important source of human infection. Aeromonas species have furthermore been recovered from fresh water sources, and some isolates are resistant to chlorination, which makes it a further risk factor (Handfield et al, 1996). In this study, Aeromonas spp. did not detected in water samples used for cleaning in meat preparation and markets. This is might be correlated with the chlorination of the water which used in the slaughterhouse and retail markets selling. Indeed, no large food- or waterborne outbreaks have been reported so far with Aeromonas spp.

The Aeromonas species, most commonly A. hydrophila have been isolated from human infections and have shown to produce a variety of biologically active extracellular products, these include hemolysins, cytotoxins, enterotoxins, beside the structural features and the cellassociated factors including endotoxin, outer membrane proteins and adhesions as well as the ability 
of $A$. hydrophila to invade host cells and disseminate to virtually any organ via blood, all of these factors are responsible for the virulence and pathogenicity of Aeromonads (Wadstrom and Ljungh, 1991; Chopra and Houston, 1999). In this study, aero $A$ gene were detected in all $A$. hydropila isolates by a prevalence of $27.5 \%$ which was lower than that of previous studies Wang et al (2003) and Zhu et al (2007) in china and Singh et al (2008) whereas it was higher than that detected by Nagar et al (2011) in India. Some Aeromonas spp. are clearly psychrotrophs, being capable to survive and grow at refrigeration temperature in a variety of food products (Mano et $\boldsymbol{a l}, 2000)$ and many keep the ability to express virulence factors (Kirov et al, 1993).

Results showed that out of 40 isolates from meat samples, 9 (22.5 $\%)$ was lipase gene positive by PCR amplification yielded band at 760 bp. The detection rate of Lipase gene was $30 \%, 0 \%, 40 \%$, and $20 \%$ among fresh beef, frozen beef, fresh poultry and frozen poultry, respectively. Among of 5 isolates from meat handlers' hands, $1(20 \%)$ was positive for lipase gene. For lipase gene was detected $22.5 \%$ which less than Nagar et al (2011) in India.

PCR results revealed that out of 40 isolates from meat samples, 29 $(72.5 \%)$ was Act gene positive by PCR amplification. Among of 5 isolates from meat handlers' hands, $4(80 \%)$ was positive for Act gene. These results was agreed with In previous studies (Abbey and Etang, 1988; Gautam et al, 1992; Agarwal et al, 1999 and Zaki et al, 2001), while it was nearly similar to that of Kingombe et al (2010) and less than that recorded by Castilho et al, (2009) and Nagar et al (2011). The detection of virulence genes by high frequencies among fresh and frozen meat indicated a high virulence of the isolated A. hydrophila strains and emphases the high risk of human infection by consuming undercooked meat.

In conclusion, the high frequencies of isolation of Aeromonas spp. from contamination of fresh and frozen meat and from food handlers and relatively high detection of virulence genes indicated a potential risk of food poisoning infections. The predominance of $A$. hydrophila should be considered as an important etiologic agent of human infections via food contamination. The potential health risks posed by consumption of these raw or undercooked food products should not be underestimated.

\section{Acknowledgements}

We are very grateful to Dr Ahmed El-Garhy, the meat inspector veterinarian and the director of Ismailia abattoir for help on sample collections.

\section{References}


Abbey, S. D. and Etang, B.B. (1988): Virulence factors from Aeromonas species. Microbial. 56 (227) 71-77.

Abd El-Rahman, A.M.M. (1996): Studies on bacterial disease among culture Tilapias. M.V.Sc. Thesis (Fish diseas and mangment) faculty Vet. Med. Suez Canal University.

Agarwal, R. K.; Kapoor, K. N.; Kalicharan, A. K.; Bhilegaonker, K. N. and Kumar, A. (1999): Paw oedema test a sensitive bioassay model for detection of enterotoxigenic potential of Aeromonas toxins. Indian $\mathrm{J}$. Toxical., 6 (1): 33- 38.

Amin, N. E. (1993): Studies on Aeromonas hydrophila isolates from fish reared in reused wastewater in Egypt. J. Egypt. Vet. Med. Ass., 53(1/2) 129:132.

Andrew, D. E.; Lenore S. C.; Eugene, W. R. and Arnold, E. G. (2005): Standard methods for the examination of water and wastewater $21^{\text {st }}$ edition.

Arora, S.; Agarwal, R.K. and Bist, B. (2006): Comparison of ELISA and PCR Vis-a'-Vis cultural methods for detecting Aeromonas spp. in foods of animal origin. International Journal of Food Microbiology 106 (2006) 177 183.

Borch, E. and Arinder, P. (2002): Bacteriological safety issues in red meat and ready-to-eat meat products, as well as control measures. Meat Science, 62 (10), pp. 381-390.
Borrego, J.Y.; Morinigo, M.A.; Marting - Manzanares E. ; Bosca M. Dolores castro, Barja J.L. and A Licia E. Torazao (1991): Plasmid associated virulence properities of environmental isolates of Aeromonas hydrophila. J. Med. Microbiol, Vol 35 (1991) 264-269.

Buchanan, R.L. and Palumbo, S.A. (1985): Aeromonas hydrophila and Aeromonas sobria as potential food poisoning species. A review. J. Food Safety, 7: 15-29.

Cascón, A.; Anguita, J.; Hernanz, C.; Sánchez, M.; fernández, M. and Naharro, G. (1996): Identification of Aeromonas hydrophila hybridization group 1 by PCR assays. Appl. Environ. Microbial., p. 1167-1170 Vol. 62, No. 4.

Castilho, M.C.' Castro, T.L.; Araújo, V.S.; Trajano, R.S.; Santos, P.A.; Pimenta, P.M.; Lucheze, K.; Melo, J.T.; Gonçalves, A.M.; Nogueira, R.T.; de Luna, M.G.; and FreitasAlmeida, A.C. (2009): High frequency of hemolytic and cytotoxic activity in Aeromonas spp. isolated from clinical, food and environmental in Rio de Janeiro, Brazil. Antonie Van Leeuwenhoek 96:53-61.

Chopra, A. K. and Houston, C.W. (1999): Enterotoxins in Aeromonas associated gastroenteritis. Microbes Infect. 1:1129-1137.

Delabre, K.; Cervantes, P.; Lahoussine, V. and Roubin, $M$ 
(1998): Detection of viable pathogenic bacteria from water samples by PCR. OECD workshop molecular methods for safe drinking water 1-8.

Efuntoya, M.O. (1995): Diarrhea disease in livestock assicated with Aeromonas hydrophila biotype I. J. Gen. App. Microbiol., 41 (6): $517-$ 521.

\section{Elshafey,}

A.M.

(2000):

Comparative Studies on Aeromonas hydrophila of aquatic and human origin with reference to virulence. Ph. D. Thesis (BacteriologyImmunology and Mycology), Fac. Vet. Med. Suez Canal University.

El-Shenawy, M. A. and Marth, E. H. (1990): Aeromonas hydrophila in food: a review. Egypt. J. Dairy Sci., 18 (2): 919-234.

Fontes, M.C.; Saavedra, M.J.; Martins, C. and MartínezMurcia, A.J. (2011): Phylogenetic identification of Aeromonas from pigs slaughtered for consumption in slaughterhouses at the North of Portugal. International Journal of Food Microbiology 146 (2011) 118122.

Fricker, C. R. and Tompsett, S. (1989): Aeomonas spp. in foods: A significant cause of food poisoning. Int. J. Food Microbial., 9:17-23.

Gautam, A. R.; Pathak, S. P.; Ramteke, P. W. and Bhattacharjee, J. W. (1992): Virulence factors in environmentenal isolates of Aeromonas spp. J. Gen. Appl. Microbial., 38: 185- 189.
Graf, J. (1999): Diverse restriction fragment length polymorphism patterns of the PCR-amplified 16S rRNA genes in Aeromonas veronii strains and possible misidentification of Aeromonas species. J. Clin. Microbiol. 37, 3194- 3197.

Handfield, M.; Simard, R; Couillard, $M$. and Letarte $R$. (1996): Aeromonas hydrophila isolated from food and drinking water: Haemagglutination, hemolysis, and cytotoxicity for a human intestinal cell lin (HT-29). Appl. Environ. Microbial., 62:34593461.

Hanninen, M.L.; Salmi, S.; Mattila, L.; Taipalinen, R. and Siitonen, A. (1995): Association of Aeromonas spp. With travelers diarrhea in Finland. J. Med. Microbial. 42(1):26-31.

Hardly, T.C.; Todd, L.S. and Stringer, M.F. (1986): Toxin production by Aeromonas hydrophila in bacteriological media and foods. Zent. Bakeriol. Hyg., 15 :165- 176.

Harrigan W. F. (1998): Laboratory methods of food microbiology. Third edition. Academic Press. 525 B Street, Suite 1900, San Diego, California 92101 - 4495, USA.

Hiney, M.P. and Smith, P.R. (1998): Validation of polymerase chain reaction - based techniques for proxy detection of bacterial fish pathogens: framework, problems and possible solutions for 
environmental

Aquaculture 162, 41-68.

applications.

Isonhood, J.H. and Drake, M. (2002): Aeromonas species in foods. J. Food Prot., 65:575-582.

Janda, J.M., and Abbott, S.L. (1998): Evolving concepts regarding the genus Aeromonas: an expanding panorama of species, disease presentations, and unanswered questions. Clin. Infect. Is. $27: 332-344$.

Kingombe, C.; Huys, G.; Tonolla, M.; Albert, M; Swings, J.; Peduzzi, R.; and Jemmi, T. (1999): PCR Detection, Characterization, and Distribution of Virulence Genes in Aeromonas spp. p. 5293-5302 Vol. 65, No. 12, American Society for Microbiology.

Kingombe, C. I.; Aoust, J.Y. D.; Huys, G.; Hofmann, L.; Rao, M.; Kwan, J. (2010): Multiplex PCR method for detection of three Aeromonas enterotoxin genes. Applied and Environmental Microbiology 76, 425-433.

Kirov, S. M.; Ardestani, E. K. And Hayward, L. J. (1993): The growth and expression of virulence factors at refrigeration temperature by Aeromonas strains isolated from foods. Inter. J. food Microbial., 20: 159-168.

Krieg, N.R. and Holt, Y. G. (1984): Bergey's manual of systemic bacteriology Williams and Wilking, Baltimore, London, Vol. 1

Kumar, A.; Bhilegaonker, K. N. and Bachhil, V. N. (2000):
Biological characterization of partially purified exotoxins of Aeromonas spp. Indian journal of comparative microbiology.

MacFaddin, J. F. (2000): Biochemical tests for identification of medical bacteria $3^{\text {rd }}$ Ed., Lippincoti williaris and Willoins. Washington, Philadelphia, USA.

Mano, S.B., Ordoñez, J.A., Garcia de Fernando, G.D.(2000): Growth/survival of natural flora and Aeromonas hydrophila on refrigerated uncooked pork and turkey packaged in modified atmospheres. Food Microbiology 17, 657-669.

Martinez-Murcia, A. J.; Benlloch, S. and Collins, M. D. (1992): Phylogenetic Interrelationships of Members of the Genera Aeromonas and Plesiomonas as Determined by 16s Ribosomal DNA Sequencing: Lack of Congruence with Results of DNA-DNA Hybridizations. Internationjaolu Rnal Of Systematibca Cteriologjyul,y 1992, p. 412-421.

Megahed A. A. (2000): Study on some Gram negative bacteria of fish. M. V. Sc. Thesis (Bacteriology- Immunology and Mycology), Fac. Vet. Med. Suez Canal University.

Nagar, V.; Shashidhar, R. and Bandekar J. (2011): Prevalence, characterization, and antimicrobial resistance of Aeromonas strains from various retail food products in Mumbai, India. J. Food Sci.76 (7):486-492. 


\section{Neyts, K.; Huys, G.; \\ Uyttendaele1, M.; Swings; J. and Debevere, J. (2000): Incidence and identification of mesophilic Aeromonas spp. from retail foods. Letters in Applied Microbiology 2000, 31, 359-363. \\ Neyts, K.; Huys, G., Uyttendaele, M.; Swings, J. and Debevere, J. (2011): Incidence and identification of mesophilic Aeromonas spp. from retail foods. J. Appl. Microbial. 110(3):823-30.}

Osman, K.; Aly, M.; Kheader, A. and Mabrok, K. (2012): Molecular detection of the Aeromonas virulence aerolysin gene in retail meats from different animal sources in Egypt. World J. Microbiol. Biotechnol. 28(5):1863-70.

Oxoid (1995): The Oxide manual $7^{\text {th }}$ edition Bridson, F. Y. (ed), Alphaprint. Alton, Hants, U. K.

Paniagua, C.; Rivero, O.; anguita, J. and Naharro, G. (1990): Pathogenicity factors and virulenence for rainbow trout of motile Aeromonas spp. isolated from a river. J. Clin. Microbial. 28 (2): 350-355.

Popoff, M.Y; Caynautt, C.; Kiredjian, M. and Lemelin $M$. (1981): Polynucleotide sequence relatedness among motile Aeromonas species. Curr. Micbiol. 5: 109-114.

Roberts, R.J. (1978): Fish pathology. $1^{\text {st }}$ Ed., Bailliere Tindall, London.

Santos, J.A.; Cesar, J.G.; Andres, O.; Garcia-Lopez, M.L.; (1999):
Hemolytic activity and siderophore production in different Aeromonas species isolated from fish. Appl. Environ. Microbiol. 65, 56125614.

Shalaby, M. A. (1997): Studies of Virulence factors of some Pseudomonadaceae and Vibrionaceae micro-organism isolated from freash and frozen fish. $\mathrm{Ph}$. D. Thesis (Microbiology) Fac. Vet. Med. Suze Canal Univ.

Singh, V.; Rathore, G.; Kapoor. D,; Mishra, B. and Lakra, W. (2008): Detection of aerolysin gene in Aeromonas hydrophila isolated from fish and pond water. Indian J. Microbiol. 48:453-458.

Surendran, D. (2002): Detection of Salmonella from foods by polymerase chain reaction. M.V.Sc. Thesis Deemed University, IVRI, Izatnagar, India.

Van Eys, G. M.; Gravekamp, C.; Gerritsen, M.; Quint, W.; Cornelissen, M.; Schegges, J. and Terpstra, W. (1989): Detection of leptospires in urine by polymerase chain reaction. J. Clin. Microbiol. 27:2258- 2262.

Ventura, C.; Civera, T. and Grassi, M.A. (1998): Aeromonas ed alimenti: rischi sanitari e modalità di controllo. Ind. Alim., 37, 982.

Vila, J.; Ruiz, J.; Gallardo, F.; Vargas, M., Soler, L.; Figueras, M. J. and Goscon, J. (2003): Aeromonas spp. and travelers diarrhea clinical features and 
antimicrobial resistance. Energy Infect Dis., 9(5)552-555.

Wadstrom, T. and Ljungh, A. (1991): Aeromonas and Plesiomonas as food- and waterborne pathogens. Int J. Food Microbial., 12:303-311.

Wang, G.; Clark, C.; Liu, C.; Pucknell, C.; Munro, C.; Kruk, T.; Caldeira, R.; Woodward, D. and Rodgers, F. (2003): Detection and Characterization of the Hemolysin Genes in Aeromonas hydrophila and Aeromonas sobria by Multiplex PCR. Journal of Clinical Microbiology, p. 10481054 Vol. 41, No. 3.

Yogananth, N.; Bhakyaraj, R.; Chanthuru, A.; Anbalagan, T. and Mullai Nila, K. (2009): Detection of Virulence Gene in
Aeromonas hydrophila Isolated from Fish Samples Using PCR Technique. Global Journal of Biotechnology \& Biochemistry 4 (1): 51-53, 2009 Pudukkottai, Tamil Nadu, India-622 404.

Zaki, M.M.; Mohamed, S.R.; Salman, A.M. and Seleim, R.S. (2001): Enterotoxigenicity of Aeromonas species isolated from different sources. Inhibitory effect of essential oils on their growth. Veter. Medi. J. Giza., 49 (1): 111121.

Zhu, D.; Li, A.; Wang, J.; Li, M.; Cai, T.; (2007): Cloning expression and characterization of aerolysin from Aeromonas hydrophila in Escherichia coli. Indian J. Biochem. Biophys. 44, 204-208. 


\section{الملخص العربي}

تهدف الدراسة الحالية إلي تحديد الصفات الظاهرية و الوراثية للأيروموناس هيدروفيلا المعزولة

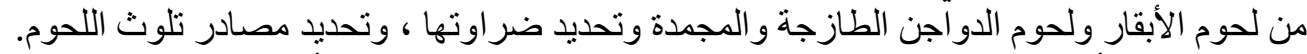

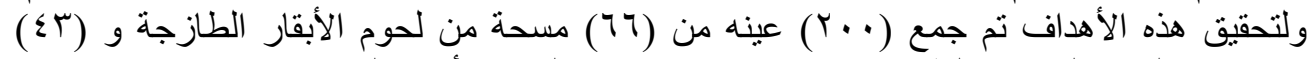

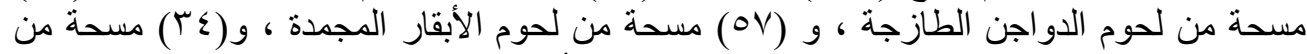

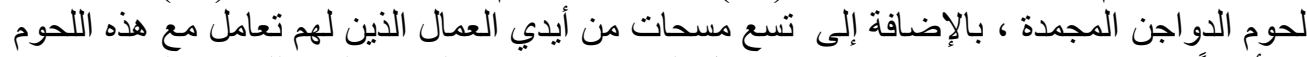

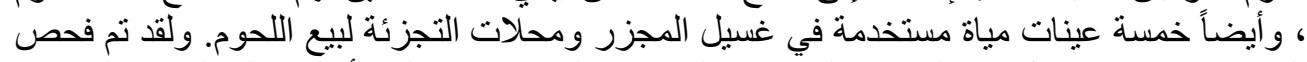

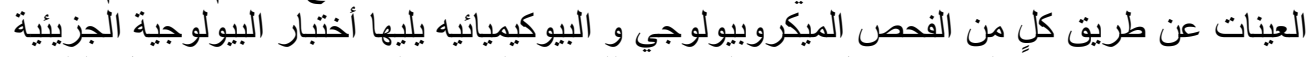

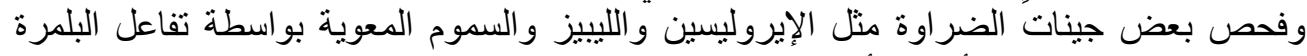

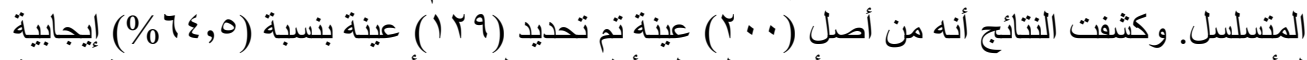

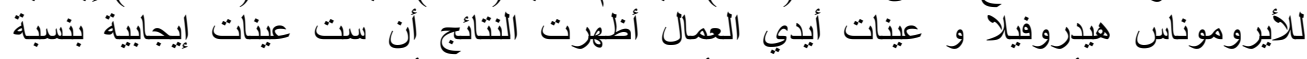

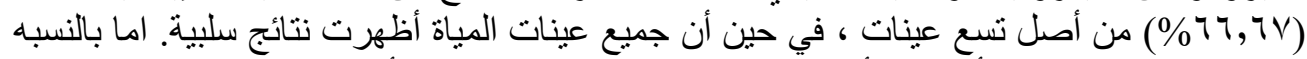

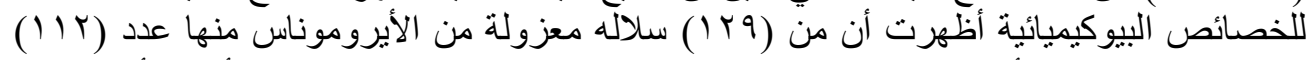

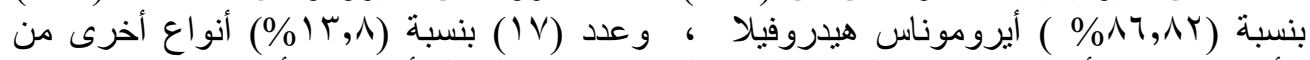

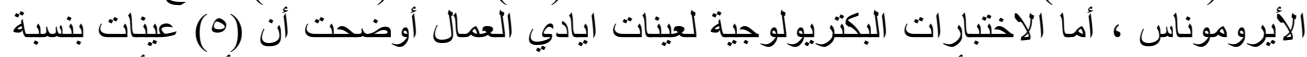

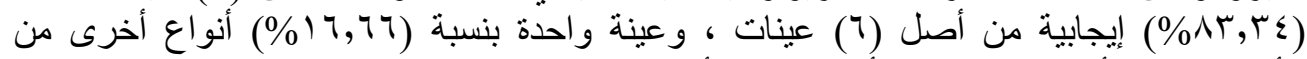

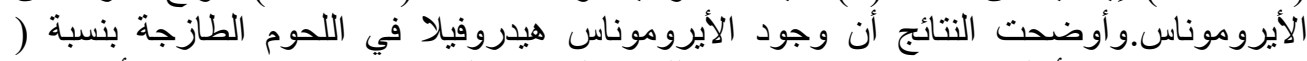

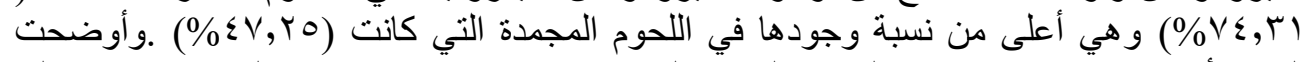

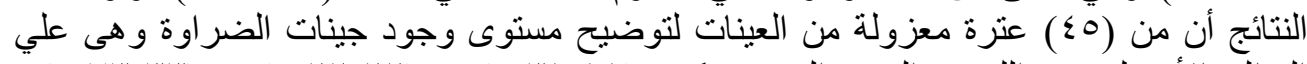

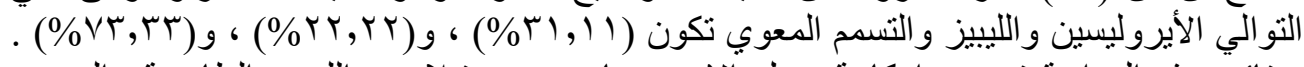

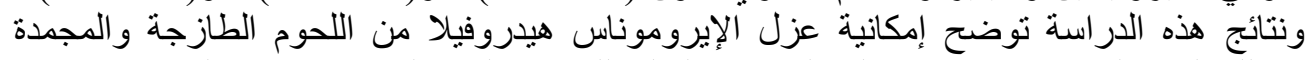

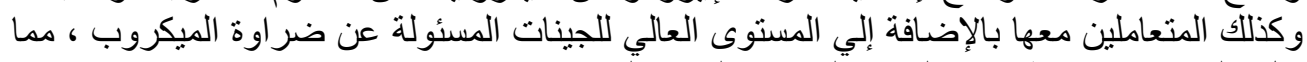

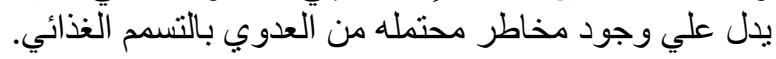

